DOI: 10.38136/jgon.727368

\title{
Gebeliğin İntrahepatik Kolestazıyla Antenatal Aneuploidi Serum Tarama Markerları Arasında İlişki Var mı?
}

\section{Is there a relationship between intrahepatic cholestasis of pregnancy and antenatal aneuploidy serum screening markers?}

\author{
Hasan EROĞLU \\ Harun Egemen TOLUNAY \\ Neval Çayönü KAHRAMAN \\ Nazan Vanlı TONYALI \\ Dilek ȘAHIIN \\ Aykan YÜCEL \\ Salim ERKAYA
}

(1) Orcid ID:0000-0003-2565-6789

(1) Orcid ID:0000-0003-1202-9823

(1) Orcid ID:0000-0003-0499-5722

(1) Orcid ID:0000-0002-9027-1351

(1) Orcid ID:0000-0003-0499-5722

(1) Orcid ID:0000-0001-6763-9720

(1) Orcid ID:0000-0001-6763-9720

${ }^{1}$ Etlik Zübeyde Hanım Kadın Hastalıkları Eğitim ve Araștırma Hastanesi, Ankara, Türkiye

\section{öz}

Giriş: Bu çalışmanın amacı antenatal dönemde yapılan serum tarama testlerindeki biokimyasal markerlerin gebeliğin intrahepatik kolestazını öngörebilme özelliğinin araştırımasıdır.

Gereç ve yöntemler: Bu vaka - kontrol gruplu çalışmada retrospektif olarak hasta kayıtları değerlendirilmiştir. Çalışmaya gebelik kolestazı tanısı alan 49 gebe ile kontrol grubu olarakta 116 sağ|ıkı gebe kadın dahil edilmiştir.

Bulgular: Ikinci trimesterde taranan alfa -fetoprotein (AFP) MoM , unkonjuge estriol (E3) MoM ve total $\beta$-HCG MoM değerleri, her 2 grupta benzerdi $(p=0.299$, $\mathrm{p}=0.571, \mathrm{p}=0.285$ ). Birinci trimester tarama testi parametresi olan PAPP-A MoM değerine bakıldığında , kolestaz tanısı almış grup ile kontrol grubu arasında fark saptanmamıştır $(p=0.103)$.

Sonuç: Sonuç olarak çalışmamızda birinci ve ikinci trimesterdeki prenatal serum tarama testlerinde bakılan biokimyasal markerler intrahepatik kolestazı öngörmede yetersiz kalmıştır.

Anahtar kelimeler: PAPP-A, $\beta$-hCG, gebeliğin intrahepatik kolestazı, gebelikte tarama testleri,

\section{Gíriş}

Gebeliğin intrahepatik kolestazı, gebelik sırasında ortaya çıkan ve gebeliğe özgü en sık görülen karaciğer hastalığıdır. Genellikle gebeliğin üçüncü trimesterinde ; kaşıntı, artmış serum transaminaz enzimleri ve artmış serum safra asitleri ile ortaya çıkar (1). Semptomlar ve kandaki biyokimyasal değişiklikler doğum sonrası hızlıca gerilemektedir ; fakat bir sonraki gebelikte veya hormonal kontrasepsiyon kullanımı ile tekrarlayabilme olasılığı vardır. İntrahepatik kolestazın insidansı dünya çapında $\% 0.2$ ve $\% 25$ arasında değişmektedir (2). Avrupadaki tüm gebeliklerin $\% 0.5$ ile $\% 1.5$ 'unu oluşturur ve en yüksek insidans

\section{ABSTRACT}

Aim: This study aims to investigate the role of biochemical markers for predicting intrahepatic cholestasis of pregnancy in antenatal screening tests.

Material and methods: Patient records were evaluated retrospectively in this case-control group study. We included forty-nine patients with pregnancy cholestasis and 116 healthy pregnant women as a control group to the study.

Results: Alpha-fetoprotein (AFP) MoM, unconjugated estriol (E3) MoM and total B-HCG MoM values were similar in both groups $(p=0.299, p=0.571, p=0.285)$. There was no difference was found between the group diagnosed with cholestasis and the control group, when the PAPP-A MoM value is examined, which is the first trimester screening test parameter $(\mathrm{p}=0.103)$.

Conclusion: In conclusion, biochemical markers examined in prenatal screening tests in the first and second trimesters were insufficient to predict intrahepatic cholestasis of pregnancy.

Keywords: PAPP-A, $\beta$-hCG, intrahepatic cholestasis of pregnancy, screening tests in pregnancy

İsveç'dedir (3). Çin'de ise \%2.3 ile \%6 arasında insidansı vardır (4). İntrahepatik kolestazın olumsuz gebelik sonuçları ile ilişkisi saptanmıştır.Bunlar arasında spontan veya iatrojenik preterm doğum ,fetal distress, mekonyum boyalı amniyon sıvısı ve artmış ölü doğum vardır. Fetus için komplikasyon riski maternal serum safra asitleri seviyesi ile ilişkilidir ve daha yüksek safra asidi düzeyine sahip olan şiddetli kolestazı olan kadınlar daha risklidir (5-9).

Gebelikte intrahepatik kolestazın etyolojisi tam olarak anlaşılamamıştır, ancak genetik olarak duyarlı kadınlarda seks steroid hormonlarının kolestatik etkisi ile ilişkili görünmektedir. Üreme hormonlarının rolüne dair kanıtlar , hastalığın doğal 
geçmişinden ve ayrıca erken doğum eylemini önlemek için oral progesteronun uygulandığı çalışmalardan gelir (10) .

Illk trimesterde düşük PAPP-A düzeyi, preeklampsi, intrauterin gelişme geriliği ve erken doğum gibi birçok gebelik komplikasyonuyla ilişkilendirilir (11). Bu çalışmada; Prenatal taramada kullanılan birinci ve ikinci trimester maternal serum biyokimyasal belirteçlerindeki değişikliklerin gebeliğin intrahepatik kolestazı ile ilişkili olup olmadığını amaçladık.

\section{GEREÇ VE YÖNTEMLER}

Bu vaka - kontrol gruplu çalışma retrospektif olarak dizayn edilmiştir. Ankara Etlik Zübeyde Hanım Kadın Hastalıkları ve Doğum Hastanesinde, hastane kayıtları 2018 ve 2019 yılları arasını kapsayacak şekilde yapılmışıı. Çalışmaya gebelik kolestazı tanısı alan 49 gebe ile kontrol grubu olarakta 116 sağlıklı gebe kadın dahil edilmiştir. Bu çalışma için Ankara Etlik Zübeyde Hanım Kadın Hastalıkları ve Doğum Hastanesinden etik kurul onayı alınmıştır (5/20-07). İntrahepatik kolestaz tanısı için şu kriterler kullanılmışı;; 3.trimesterde kaşıntı şikayeti olması , açlık safra asit düzeyleri $>10 \mathrm{mmol} / \mathrm{L}$ olması ve doğum sonrası şikayetlerde gerileme olması (8). Kontrol grubundaki gebe kadınlar, yaş ve vücut kitle endeksi (VKI) benzer sağlıklı gebe kadınlardan oluşmaktadır. Gestasyonel diabetes mellitus (GDM), preeklampsi, eklampsi, kronik karaciğer hastalığı olan ve çogul gebeliği olan gebeler çalışmaya dahil edilmemiştir. Tüm hastaların birinci trimester tarama testlerindeki pregnancy associated plasma protein A (PAPP-A) MoM değerleri ve ikinci trimester tarama testi biokimyasal markerları olan alpha-fetoprotein (AFP), unconjugated estriol (uE3), ve human chorionic gonadotropin'in (hCG) MoM değerleri retrospektif olarak hastane kayıtlarından elde edilmiştir. Aynı zamanda yaş, gravida, parite, gestasyonel yaş gibi demografik özellikler retrospektif olarak hastane kayıtlarından elde edilmişir.

İstatistiksel analizlerde SPSS versiyon 15 yazılımını kullandık. Değişkenlerin normal dağılıma uygunluğu Kolmogorov-Smirnov testi ve histogram kullanılarak test edilmiştir. Tanımlayıcı analizlerde sonuçlar ortalama $\pm S S$ ve ortanca kullanılarak verildi. PAPP-A, AFP, uE3, ve hCG değerlerinin normal dağılım göstermediği belirlendiğinden Mann-Whitney U Testi uygulandı. P-değerinin 0.05 'in altında olduğu durumlar istatistiksel olarak anlamlı kabul edildi.

\section{BULGULAR}

Intrahepatik kolestaz tanılı gebeler ve kontrol grubunun temel karakteristik özellikleri ve sonuçları Tablo 1 'de gösterilmiştir.
Ortalama yaş kolestaz grubunda $(30,02 \pm 5,89)$ anlamlı olarak, kontrol grubuna göre daha yüksek olarak saptandı $(p<0,01)$. Sağlıklı gebelerle kolestazlı gebelerin VKİ, gravide, parite ve abortus değerleri açısından istatistiksel olarak anlamlı bir fark saptanmamıştır. Doğum haftası kolestaz grubunda (37,2 \pm $1,47)$ anlamlı olarak kontrol grubuna göre daha düşük hafta $(39,16 \pm 1,0)$ olarak bulunmuştur. Doğum kilosuna bakıldığında kolestaz grubunda (3167 \pm 473 ) kontrol grubuna göre ortalama

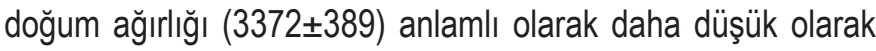
saptanmıştır $(p<0,01)$.

Tablo 1. Kontrol grubu ile gebelik kolestazı tanılı hastaların demografik özellikleri ve perinatal sonuçlarına göre karşılaştırılması

\begin{tabular}{|c|c|c|c|c|c|}
\hline \multirow[b]{2}{*}{ Değişkenler } & \multicolumn{2}{|c|}{ Kolestaz $(n=49)$} & \multicolumn{2}{|c|}{ Kontrol (n=116) } & \multirow[b]{2}{*}{ p* } \\
\hline & $\begin{array}{l}\text { Ortalama } \\
\pm S S\end{array}$ & $\begin{array}{l}\text { Or- } \\
\text { tanca }\end{array}$ & $\begin{array}{l}\text { Ortalama } \\
\pm S S\end{array}$ & $\begin{array}{l}\text { Or- } \\
\text { tan- } \\
\text { ca }\end{array}$ & \\
\hline Yaş & $30,02 \pm 5,89$ & 30 & $26,85 \pm 5,05$ & 26 & $<0,01$ \\
\hline BMI & $29,03 \pm 4,79$ & 28,0 & $29,08 \pm 4,20$ & 29 & 0,926 \\
\hline Gravide & $2,10 \pm 1,14$ & 2,1 & $2,22 \pm 1,06$ & 2,0 & 0,511 \\
\hline Parite & $0,84 \pm 0,921$ & 1,0 & $0,89 \pm 0,821$ & 1,0 & 0,725 \\
\hline Abortus & $0,35 \pm 0,69$ & 0,0 & $0,34 \pm 0,61$ & 0,0 & 0,894 \\
\hline $\begin{array}{l}\text { Doğum } \\
\text { haftası }\end{array}$ & $37,2 \pm 1,47$ & 37,0 & $39,16 \pm 1,0$ & 39,3 & $<0,01$ \\
\hline Apgar 1.min & $8,84 \pm 0,59$ & 9,0 & $8,94 \pm 0,46$ & 9,0 & 0,04 \\
\hline Apgar 5.min & $9,84 \pm 0,59$ & 10 & $9,96 \pm 0,33$ & 10 & 0,04 \\
\hline $\begin{array}{l}\text { Doğum ki- } \\
\text { losu }\end{array}$ & $3167 \pm 473$ & 3120 & $3372 \pm 389$ & 3355 & $<0,01$ \\
\hline
\end{tabular}

SS: Standart Sapma

Birinci ve ikinci trimester serum tarama testi parametreleri tablo 2'de gösterilmiştir. İkinci trimesterde taranan AFP MoM ,E3 MoM , total BHCG MoM değerleri kolestaz tanılı grup ile kontrol grubu arasında benzer olarak saptandı (sırasıyla $p=0.299$ , $p=0.571, p=0.285$ ). Birinci trimester tarama testi parametresi olan PAPP-A MoM değerine bakıldığında , kolestaz tanısı almış grup ile kontrol grubu arasında fark saptanmamıştır $(p=0.103)$. Tablo 2 'de her iki grup arasında karaciğer enzimi olan AST ve ALT değerleri de karşılaştııımıştır. Kolestaz tanısı alımış gebe grubunda ,kontrol grubuna göre AST ve ALT değerleri anlamlı olarak yüksek bulunmuştur $(p<0,01)$. 
Tablo 2. Kontrol gubu ile gebelik kolestazı tanılı hastaların PAPP-A, alpha-fetoprotein (AFP), unconjugated estriol (uE3), ve human chorionic gonadotropin (hCG) sonuçları açısından karşılaştırılması

\begin{tabular}{|c|c|c|c|c|c|}
\hline & \multicolumn{2}{|c|}{ Kolestaz(n=49) } & \multicolumn{2}{|r|}{ Kontrol(n=116) } & \multirow[b]{2}{*}{$\mathrm{p}^{*}$} \\
\hline Değişkenler & Ortanca & $\begin{array}{l}\text { Minimum-Mak- } \\
\text { simum }\end{array}$ & Ortanca & $\begin{array}{l}\text { Mini- } \\
\text { mum-Maksi- } \\
\text { mum }\end{array}$ & \\
\hline PAPP-A MoM & 1,41 & $0,29-9,20$ & 1,14 & $0,29-4,18$ & 0,103 \\
\hline $\begin{array}{l}\text { alpha-fetoprote- } \\
\text { in (AFP) MoM }\end{array}$ & 1,00 & $0,61-2,90$ & 0,99 & $0,29-2,74$ & 0,299 \\
\hline $\begin{array}{l}\text { unconjugated } \\
\text { estriol (uE3) } \\
\text { MoM }\end{array}$ & 0,80 & $0,23-10,60$ & 0,97 & $0,33-2,18$ & 0,571 \\
\hline $\begin{array}{l}\text { human chorionic } \\
\text { gonadotropin } \\
\text { (hCG) MoM }\end{array}$ & 0,97 & $0,25-3,00$ & 0,93 & $0,39-2,68$ & 0,285 \\
\hline $\begin{array}{l}\text { gonadotropin } \\
\text { (hCG) gonadot- } \\
\text { ropin (hCG) }\end{array}$ & & & & & \\
\hline AST & 36 & $10-164$ & 17 & $10-71$ & $<0,01$ \\
\hline ALT & 44 & $3-413$ & 9 & $4-56$ & $<0,01$ \\
\hline
\end{tabular}

${ }^{*}$ Mann Whitney U testi

\section{TARTIŞMA}

Gebelikte intrahepatik kolestaz, gebelik sırasında ortaya çıkan spesifik bir karaciğer hastalığıdır. Genellikle gebeliğin üçüncü trimesterinde, kaşıntı, artmış serum transaminaz enzimleri ve artmış serum safra asitleri ile ortaya çıkar (9). Semptomlar ve kandaki biyokimyasal değişiklikler doğum sonrası hızlıca gerilemektedir ; fakat bir sonraki gebelikte de tekrarlayabilme olasılığı vardır. Birinci ve ikinci trimesterde yapılan prenatal tarama testleri, daha çok Down sendromunu tanımak ve maternal , fetal sonuçlarla olan ilişkisini ortaya koymak için yapılan testlerdir. Biz de bu çalışmamızda prenatal serum tarama testlerini kullanarak maternal ve fetal sonuçları olumsuz etkileyebilen, gebeliğin intrahepatik kolestazını önceden öngörebilmede bir yerinin olup olmadığını araştırmayı planladık.

Düşük PAPP-A değerinin Down Sendromunu öngörebildiği gibi ,gebeliğin ileri dönemlerinde intrauterine ölüm ,fetal gelişim geriliği, preeklampsi, gestasyonel diabetes mellitus , preterm eylem ve doğum riskini artırdığı gösterilmiştir (12-16) . Literatüre baktığımız zaman ikinci trimesterdeki prenatal tarama testinde yapılan yüksek AFP MoM , BHCG ve düşük E3 düzeylerinin gebelikte preterm eylem ile ilişkili olduğu ortaya koyulmuştur (17). Bizim bu çalışmamızdaki verilerimizin gebelikteki intrahepatik kolestazı önceden öngörmede yetersiz kaldığını görmekteyiz.

PAPP-A, insülin benzeri büyüme faktörü (IGF) sisteminin bir modülatörü olan, insülin benzeri büyüme faktörü bağlayıcı protein 4 (IGFBP-4)'ün parçalanmasını kolaylaştıı [18]. Düşük PAPP-A seviyelerinde, IGFBP-4'ün yıkımı azalacağı için, maternal serumda serbest IGF düzeyleri azalıp, desidual trofoblastik invazyon bozulur [19]. Sonuç olarak; bu olumsuz gebelik sonuçlarına neden olabilir.Birçok çalışmada düşük PAPP-A değerlerinin dolaşımdaki IGF düzeyini azaltarak preterm eylem , preeklampsi, gestasyonel diabetes mellitus ve intrauterin ölüm gibi gebelikte olumsuz sonuçlara neden olduğu gösterilmiştir $(20,21)$. Buna ek olarak önceki çalışmalarda da kolestatik ratlarda IGF tedavisinin safra asit düzeylerini azaltarak terapötik etki elde edildiği bildirilmiştir (22).

Tayyar ve ark. , birinci trimesterde saptanan düşük PAPP-A değerinin gebelikte kolestazı öngördüğünü göstermişlerdir. Düşük PAPP-A seviyesinin IGF yolu üzerinden intrahepatik kolestaz gelişimi ile ilişkili olabileceği değerlendirilmiştir. Bizim çalışmamızda PAPP-A değerinin intrahepatik kolestazı öngörmede yetersiz olduğu gözlenmektedir (23).

Gebelikte artmış östrojen ve progesteron bazı kadınlarda safra asit taşıyıcı pompayı inhibe ederek, vücutta safra asit düzeyinin artmasına yol açabilmektedir $(24,25)$. Biz de bu bilgiden yola çıkarak E3 seviyesinin intrahepatik kolestaz etyopatogenezinde rol alabileceğini düşündük. Fakat çalışmamızda kolestaz ve kontrol grubunda E3 düzeyleri arasında anlamlı bir fark saptanmamıştır. Bu da benzer E3 seviyesine sahip gebelerde de intrahepatik kolestaz gelişebileceğini göstermektedir. Ayrıca gebelik kolestazında; vajinal PGE2 ile indüklenen multipar gebe kadınlarda artan safra asidi konsantrasyonları, daha kısa servikal olgunlaşma süresi ve daha kısa doğum indüksiyon süresi ile ilişkilidir (26).

Sonuç olarak çalışmamızda birinci ve ikinci trimesterdeki prenatal serum tarama testlerinde yapılan biokimyasal markerler intrahepatik kolestazı öngörmede yetersiz kalmıştır. Çalışmamızın retrospektif olması ve hasta populasyonunun az olması bunun nedenleri arasındadır. Daha anlamlı sonuçlar için hasta populasyonumuzun fazla olduğu prospektif bir çalışma yapılması gerektiği kanısındayız . 


\section{KAYNAKLAR}

1.Williamson C, Geenes V. intrahepatic cholestasis of pregnancy .Obstet. Gynecol 2014;124:120-33.

2. Joshi $D$, James A, Quaglia A, et al.Liver disease in pregnancy. Lancet 2010;375:594-605

3. Arrese $\mathrm{M}$, Reyes $\mathrm{H}$, Intrahepatic cholestasis of pregnancy : a past and present riddle .Ann Hepatol 2006;5:202-5

4. Qi HB, Shao Y, Wu WX, et al. Grading of intrahepatic cholestasis of pregnancy.

Zhonghua Fu Chan Ke Za Zhi 2004;39:14-7.5. Ovadia C, Seed PT, Sklavounos A, et al. Association of adverse perinatal outcomes of intrahepatic cholestasis of pregnancy with biochemical markers: results of aggregate and individual patient data meta-analyses [published correction appears in Lancet. 2019 Mar 16;393(10176):1100]. Lancet. 2019;393(10174):899-909. doi:10.1016/S0140-6736(18)31877-4

6. Glantz A, Marschall HU, Mattsson LA. Intrahepatic cholestasis of pregnancy: relationships between bile acid levels and fetal complication rates. Hepatology 2004;40:467-74.

7. Laatikainen T, Ikonen E. Fetal prognosis in obstetric hepatosis. Ann Chir Gynaecol Fenn 1975;64:155-64.

8. Laatikainen T, Tulenheimo A. Maternal serum bile acid levels and fetal distress in cholestasis of pregnancy. Int J Gynaecol Obstet 1984;22:91-4.

9. Bicocca MJ, Sperling JD, Chauhan SP. Intrahepatic cholestasis of pregnancy: Review of six national and regional guidelines. Eur J Obstet Gynecol Reprod Biol. 2018;231:180-187. doi:10.1016/j.ejogrb.2018.10.041

10. Kang JH, Farina A, Park JH, et al. Down syndrome biochemical markers and screening for preeclampsia at first and second trimester: correlation with the week of onset and the severity. Prenat Diagn 2008; 28: 704-9.

11. D'Antonio F, Rijo C, Thilaganathan B, et al. Association between first-trimester maternal serum pregnancy-associated plasma protein-A and obstetric complications. Prenat Diagn. 2013 ;33(9) . PMID: 23613261 Clinical Trial12. Gutaj P, Wender-Ożegowska E, Brazert J. Maternal lipids associated with large-for-gestational-age birth weight in women with type 1 diabetes: results from a prospective single-center study. Arch Med Sci 2017; 13: 753-9.

13. Goetzinger KR, Cahill AG, Macones GA, et al. Association of first-trimester low PAPP-A levels with preterm birth. Prenat Diagn 2010; 30: 309-13.

14. Bacq Y, Sapey T, Brechot MC, et al. Intrahepatic cholestasis of pregnancy: a French prospective study. Hepatology 1997; 26 : 358-64.

15. Roncaglia N, Locatelli A, Arreghini A, et al. A randomised controlled trail of ursodeoxycholic acid and S-adenosyl-1-methionine in the treatment of gestational cholestasis. BJOG 2004; 111: 17-21.

16. Nunthapiwat S, Sekararithi R, Wanapirak C, et al. Second Trimester Serum Biomarker Screen for Fetal Aneuploidies as a Predictor of Preterm Delivery: A Population-Based Study. Gynecol Obstet Invest. 2019;84(4):326-333. doi:10.1159/000495614

17. Chełchowska M, Gajewska J, Mazur J, et al. Serum pregnancy-associated plasma protein A levels in the first, second and third trimester of pregnancy: relation to newborn anthropometric parameters and maternal tobacco smoking. Arch Med Sci 2016; 12: $1256-62$.

18. K. Spencer, N.J. Cowans, K.H. Nicolaides.Low levels of maternal serum PAPP-A in the first trimester and the risk of pre-eclampsia.Prenat Diagn, 28 (1) (2008),

19. C.A. Conover, L.K. Bale, M.T. Overgaard, et al.Metalloproteinase pregnancy-associated plasma protein $A$ is a critical growth regulatory factor during fetal development Development, 131 (5) (2004), pp. 1187-1194

20. Gagnon A, Wilson RD, Audibert F, et al. Obstetrical complications associated with abnormal maternal serum markers analytes. J Obstet Gynaecol Can 2008; 30: 918-49.

21. Mabuchi M, Kawamura I, Fushimi M, et al. Choleretic actions of insulin like growth factor I, prednisolone, and ursodeoxycholic acid in rats. Dig Dis Sci 2003; 48: 1398-405.

22. Tayyar AT, Tayyar A, Atakul T, et al. Could first- and second-trimester biochemical markers for Down syndrome have a role in predicting intrahepatic cholestasis of pregnancy?. Arch Med Sci. 2018;14(4):846-850. doi:10.5114/aoms.2017.69865

23. Arrese M, Macias RIR, Briz O, et al. Molecular pathogenesis of intrahepatic cholestasis of pregnancy. Expert Rev Mol Med 2008; 10: e9.

24. Hagenbuch B, Dawson P. The sodium bile salt cotransport family SLC10. Pflugers Arch 2004; 447: 566-70.

25. Vallejo M, Briz O, Serrano MA, et al. Potential role of trans-inhibition of the bile salt export pump by progesterone metabolites in the etiopathogenesis of intrahepatic cholestasis of pregnancy. J Hepatol 2006; 44: 1150-7

26. Şahin B, Çelik S, Soyer C, et al. "The severity of intrahepatic 
647 EROĞLUH.

cholestasis of pregnancy can shorten the first stage of labor in Dergisi-Ortadogu Medical Journal 12.2 (2020): 251-257. multiparous women induced by prostaglandin E2." Ortadoğu Tıp 